\title{
SISTEM PENGHARGAAN TERHADAP KINERJA PERAWAT MELAKSANAKAN ASUHAN KEPERAWATAN
}

\author{
Royani $^{1,2^{*}}$, Junaiti Sahar ${ }^{3}$, Mustikasari $^{3}$ \\ 1. STIKES Banten BSD City Serpong, Tangerang Selatan 15318, Indonesia \\ 2. Program Studi Magister Fakultas Ilmu Keperawatan Universitas Indonesia, Depok 16424, Indonesia \\ 3. Fakultas Ilmu Keperawatan Universitas Indonesia, Depok 16424, Indonesia \\ *Email:royani_r@yahoo.com
}

\begin{abstract}
Abstrak
Penelitian deskriptif korelasi dan cross sectional ini bertujuan mengetahui hubungan antara sistem penghargaan dengan kinerja perawat dalam melaksanakan asuhan keperawatan di Instalasi Rawat Inap RSUD Kota C. Pengumpulan data dilakukan dengan kuesioner dan observasi. Metode Chi Square dan Multiple Logistic Regression digunakan dalam analisis data. Hasil penelitian menunjukkan tidak ada hubungan bermakna antara sistem penghargaan dengan kinerja 65 perawat ( $p$ (persepsi perawat) $=0,720$; $p($ observasi $)=0,716 ; \alpha=0,05)$. Sub variabel pengaruh dan pertumbuhan diri adalah sub variabel yang paling berhubungan dengan kinerja perawat. Rumah sakit perlu mempertimbangkan jenjang karir perawat sebagai dasar utama pemberian sistem penghargaan.
\end{abstract}

Kata Kunci: Asuhan keperawatan, kinerja perawat, sistem penghargaan

\section{Abstract}

This research aim to know relation between reward system with nurse performance in nursing care in RSUD C. Method Research use descriptive correlation with cross sectional device. Sampel use 65 nurse. Data collecting conducted with kuesioner and observation. Method Chi Square and Multiple Logistic Regression used in data analysis. Result of research found that no significant relationship between reward system with nurse performance ( $p$ nurse perception $=0,720$ and $p$ result of observation $=$ $0,716 ; \alpha=0.05)$. Sub variable influence and growth are most sub variable relate to nurse performance. The hospital require to develop nursing career as basic mayor reward system.

Keywords: Nurse performance, nursing care, reward system

\section{Pendahuluan}

Upaya mendapatkan tenaga kesehatan yang berkualitas telah dilakukan dengan mengembangkan manajemen kinerja. Insentif finansial, insentif non finansial serta beberapa faktor eksternal (fasilitas kerja, kepemimpinan, imbalan, jadwal, beban kerja, area praktik dan supervisi, serta jaminan sosial) merupakan faktor yang mempengaruhi motivasi kerja (Adji, 2002; Lusiani, 2006; Al-Ahmadi, 2009).

RSUD Kota $\mathrm{C}$ berupaya menunjukkan penghargaan kepada karyawan berupa reward, dengan reward seorang manager mendapatkan cara guna mendapatkan karyawan yang mampu bekerja sesuai tujuan organisasi (Marquis \& Huston, 2006; Notoatmodjo, 2009). Namun, data RSUD Kota C menunjukkan angka kepuasan klien menurun, di- siplin waktu rendah, serta turn over perawat RSUD Kota C tahun 2009 yaitu 11,7\%. Tujuan penelitian untuk mengidentifikasi hubungan antara sistem penghargaan dengan kinerja perawat dalam melaksanakan asuhan keperawatan di RSUD Kota C.

\section{Metode}

Jenis penelitian ini deskriptif korelasi; rancangan cross sectional. 114 perawat pelaksana RSUD Kota C menjadi populasi. Simple random sampling digunakan untuk menentukan sampel sejumlah 65 perawat. Penelitian di Instalasi Rawat Inap RSUD Kota C pada Mei sampai Juni 2010. Alat pengumpul data berupa kuesioner dan observasi. Kuesioner dalam bentuk pernyataan berkaitan data karakteristik demografi perawat dan sistem penghargaan dan kinerja perawat dalam asuhan keperawatan. 
Format observasi menggunakan format Standar Operasional Prosedur (SOP) RSUD Kota C.

\section{Hasil}

\section{Karakteristik Responden}

Hasil analisis data responden menunjukkan bahwa dari 65 responden sebagian besar DIII Keperawatan $(84,6 \%)$, rata-rata berumur 28,26 tahun $(\mathrm{SD}=$ 2,746), dan masa kerja rata-rata kategori madya 4 tahun $(\mathrm{SD}=2,847)$.
Hasil analisis sistem penghargaan menunjukkan perawat dengan persepsi sistem penghargaan pada kategori tinggi dan rendah mendekati nilai yang sama $(49,2 \%$ dan $50,8 \%)$. Sub variabel sistem penghargaan yang dipersepsikan tinggi oleh perawat sebagian besar meliputi penghargaan non finansial $(60 \%)$, terdiri dari pencapaian $(66,2 \%)$, pengakuan $(56,9 \%)$, pengaruh $(53,8 \%)$, dan pertumbuhan diri $(73,8 \%)$. Sementara sub variabel sistem penghargaan yang dipersepsikan rendah oleh perawat meliputi insentif $(53,8 \%)$ dan tanggung jawab $(55,4 \%)$.

Tabel 1. Distribusi Frekuensi Hubungan Sistem Penghargaan dengan Kinerja Perawat

\begin{tabular}{|c|c|c|c|c|c|c|c|}
\hline \multirow{3}{*}{ Variabel } & \multicolumn{4}{|c|}{ Kinerja } & \multirow{3}{*}{ Total } & \multirow{3}{*}{$\mathbf{p}$} & \multirow{3}{*}{ OR (CI 95\%) } \\
\hline & \multicolumn{2}{|c|}{ Kurang Baik } & \multicolumn{2}{|c|}{ Baik } & & & \\
\hline & n & $\%$ & $\mathbf{n}$ & $\%$ & & & \\
\hline \multicolumn{8}{|c|}{ Penghargaan } \\
\hline a. Rendah & 15 & 46,9 & 17 & 53,1 & 32 & 0,720 & 1,357 \\
\hline b. Tinggi & 13 & 39,4 & 20 & 60,6 & 33 & & $(0,507-3,634)$ \\
\hline
\end{tabular}

\section{Sub Variabel}

Ins entif

a. Rendah

b. Tinggi

Pencapaian
a. Rendah

b. Tinggi

Pengakuan

a. Rendah

b. Tinggi

Tanggung Jawab
a. Rendah

b. Tinggi

Pengaruh
a. Rendah
b. Tinggi

Pertumbuhan Diri
a. Rendah
b. Tinggi

Skala Grading
a. PK I
b. PK II
c. PK III

$\begin{array}{lll}15 & 42,9 & 2 \\ 13 & 43,3 & 17\end{array}$

$7 \quad 31,8 \quad 15$

$21 \quad 48,8 \quad 22$

$$
68,2
$$

51,2

57,1

56,7

35

30

1,000

0,981

(0,366-2,626)

$11 \quad 39,3 \quad 17$

17

45,9

60,7

54,1

38

37

0,776

0,761

(0,166-1,437)

$14 \quad 38,9 \quad 22$

\section{1,1}

$$
36
$$$$
29
$$

0,612

0,682

$14 \quad 48,3 \quad 15$

51,7

29

$(0,253-1,834)$

$\begin{array}{ccc}18 & 60 & 1 \\ 10 & 28,6 & 25\end{array}$

$\begin{array}{cc}40 & 30 \\ 71,4 & 35\end{array}$

$0,021 *$

3,750

(1,332-10,557)

$2 \quad 11,8 \quad 15$

\section{8,2}

17

$0,006^{*}$

0,113

48

(0,023-0,548)

54,2

$15 \quad 53,6$

1139,3

13

17

\section{6,4}

60,7

28

0,221

1,783

(0,617-5, 155)

4,038

(0,710-22,966) 
Perawat sebagian besar berada pada tahap jenjang karir dengan skala grading I $(43,1 \%)$ dan II $(43,1 \%)$.

Hasil analisis data kinerja yang dipersepsikan perawat berada pada kategori baik dan kurang baik dengan jumlah proporsi hampir sama $(56,9 \%$ dan 43,1\%). Hasil kinerja perawat berdasarkan observasi juga hampir sama antara kategori baik dan kurang baik (53,8\% dan 46,2\%). Hasil cross check kesesuaian dengan data kinerja kuesioner aspek pelaksanaan didapatkan kinerja perawat berdasarkan observasi maupun yang dipersepsikan perawat memiliki nilai yang sama yaitu kinerja baik $53,8 \%$ dan kurang baik $46,2 \%$.

\section{Hubungan Sistem Penghargaan dengan Kinerja Perawat}

Tabel 1 memperlihatkan ada 2 (dua) sub variabel sistem penghargaan yang memiliki hubungan bermakna dengan kinerja yang dipersepsikan oleh perawat yaitu sub variabel pengaruh $(\mathrm{p}=0,021 ; \alpha=$ $0,05)$ dan pertumbuhan diri $(p=0,006 ; \alpha=0,05)$, sementara sub variabel yang lain tidak memiliki hubungan bermakna dengan kinerja yang dipersepsikan oleh perawat. Sedangkan, hasil pada tabel 2 menunjukkan bahwa semua sub variabel sistem penghargaan tidak memiliki hubungan bermakna dengan kinerja berdasarkan observasi.

Pada tabel 3 memperlihatkan hasil analisis multivariat enam tahapan, yang menunjukkan bahwa variabel yang paling berhubungan secara bermakna dengan kinerja yang dipersepsikan perawat adalah sub variabel pengaruh. Hasil analisis didapatkan perawat yang memiliki persepsi pengaruh tinggi berpeluang 5,042 kali untuk memiliki kinerja baik dibandingkan dengan perawat yang memiliki persepsi pengaruh rendah setelah dikontrol pertumbuhan diri $(\mathrm{OR}=5,042)$.

Pada tabel 4 didapatkan hasil analisis multivariat pada sistem penghargaan dengan kinerja berdasarkan observasi dengan dua tahapan menunjukkan bahwa variabel yang paling berhubungan secara bermakna dengan kinerja perawat ada- lah pertumbuhan diri. Perawat yang memiliki persepsi pertumbuhan diri tinggi berpeluang 2,798 kali untuk memiliki kinerja baik berdasarkan observasi dibandingkan dengan perawat yang memiliki persepsi pertumbuhan diri rendah $(\mathrm{OR}=2,798)$.

\section{Pembahasan}

\section{Sistem Penghargaan dengan Kinerja Perawat}

Hasil penelitian menunjukkan bahwa kinerja yang dipersepsikan oleh perawat maupun berdasarkan dari observasi antara kategori baik dan kurang baik hampir sama, ini sejalan dengan Ilyas (2002); Wibowo (2007); Nawawi (2008) yang menyatakan bahwa kinerja dapat dilihat dari faktor motivasi, kemampuan mengerjakan pekerjaan, dan lingkungan kerja.

Hasil penelitian juga menunjukkan bahwa persepsi perawat terhadap sistem penghargaan tinggi dan rendah mendekati nilai sama. Persepsi perawat terhadap sistem penghargaan bersifat subjektif. Retnowati (2001) menyatakan bahwa persepsi terhadap imbalan terjadi tidak begitu saja tetapi ada faktor yang mempengaruhinya meliputi: sikap, motif, kepentingan, minat, pengalaman, dan harapan.

Faktor non finansial menjadi salah satu yang dipersepsikan tinggi oleh perawat karena perasaan puas pada pemenuhan kebutuhan non finansial akan jauh lebih lama terpelihara dibandingkan dengan faktor finansial. Armstrong dan Murlis (2003) mengemukakan ada dua hal memberikan kepuasan bekerja, yaitu: motivator dan Hygiene factors. Kepuasan kerja lebih sering dikaitkan dengan halhal yang berkaitan dengan prestasi, tanggung jawab, kemajuan dalam bekerja, dan karakteristik pekerjaan (Gillies, 1996).

Hasil analisis menunjukkan bahwa tidak ada hubungan antara sistem penghargaan dengan kinerja perawat. Hasil ini sesuai Sastradijaya (2004); Muharyati (2006), bahwa penyebabnya karena sistem penghargaan belum mampu menyentuh aspek profesionalisme dan kemampuan perawat. 
Tabel 2. Distribusi Frekuensi Hubungan Sistem Penghargaan dengan Kinerja Perawat Berdasarkan Observasi

\begin{tabular}{|c|c|c|c|c|c|c|c|}
\hline \multirow{3}{*}{ Variabel } & \multicolumn{4}{|c|}{ Kinerja } & \multirow{3}{*}{ Tot } & \multirow{3}{*}{$\mathbf{p}$} & \multirow{3}{*}{$\begin{array}{c}\text { OR } \\
\text { (CI 95\%) }\end{array}$} \\
\hline & \multicolumn{2}{|c|}{ Kurang Baik } & \multicolumn{2}{|c|}{ Baik } & & & \\
\hline & $\bar{n}$ & $\%$ & $\mathbf{N}$ & $\%$ & & & \\
\hline \multicolumn{8}{|c|}{ Penghargaan } \\
\hline a. Rendah & 16 & 50 & 16 & 50 & 32 & 0,716 & 1,357 \\
\hline b. Tinggi & 14 & 42,4 & 19 & 57,6 & 33 & & $(0,510-3,609)$ \\
\hline \multicolumn{8}{|c|}{ Sub V ariabel } \\
\hline \multicolumn{8}{|c|}{ Ins entif } \\
\hline a. Rendah & 15 & 42,9 & 20 & 57,1 & 35 & 0,744 & 0,750 \\
\hline b. Tinggi & 15 & 50 & 15 & 50 & 30 & & $(0,281-1,998)$ \\
\hline \multicolumn{8}{|c|}{ Pencapaian } \\
\hline a. Rendah & 11 & 50 & 11 & 50 & 22 & 0,856 & 1,263 \\
\hline b. Tinggi & 19 & 44,2 & 24 & 55,8 & 43 & & $(0,451-3,538)$ \\
\hline \multicolumn{8}{|l|}{ Pengakuan } \\
\hline a. Rendah & 11 & 39,3 & 17 & 60,7 & 28 & 0,475 & 0,613 \\
\hline b. Tinggi & 19 & 51,4 & 18 & 48,6 & 37 & & $(0,227-1,659)$ \\
\hline \multicolumn{8}{|c|}{ Tanggung Jawab } \\
\hline a. Rendah & 15 & 41,7 & 21 & 58,3 & 36 & 0,577 & 0,667 \\
\hline b. Tinggi & 15 & 51,7 & 14 & 48,3 & 29 & & $(0,249-1,785)$ \\
\hline \multicolumn{8}{|l|}{ Pengaruh } \\
\hline a. Rendah & 15 & 50 & 15 & 50 & 30 & 0,744 & 1,333 \\
\hline b. Tinggi & 15 & 42,9 & 20 & 57,1 & 35 & & $(0,500-3,553)$ \\
\hline \multicolumn{8}{|c|}{ Pertumbuhan Diri } \\
\hline a. Rendah & 11 & 64,7 & 6 & 35,3 & 17 & 0,133 & 2,798 \\
\hline b. Tinggi & 19 & 39,6 & 29 & 60,4 & 48 & & $(0,885-8,844)$ \\
\hline \multicolumn{8}{|c|}{ Skala Grading } \\
\hline a. PK I & 13 & 46,4 & 15 & 53,6 & 28 & 0,994 & 1,000 \\
\hline b.PK II & 13 & 46,4 & 15 & 53,6 & 28 & & $(0,350-2,859)$ \\
\hline c. PK III & 4 & 44,4 & 5 & 55,6 & 9 & & 1,083 \\
\hline
\end{tabular}

* bermakna pada $\alpha=0,05$

Hasil pemetaan dari sistem grading perawat hanya memberikan kontribusi $25 \%$ dari total pembobotan poin insentif perawat, yang terdiri dari komponen pendidikan, masa kerja, status kepegawaian, pelatihan, penilaian hasil kerja, dan uji kompetensi. Sementara Depkes RI dan PPNI (2006) menyatakan penentuan jenjang karir perawat dinilai dari unsur kompetensi, pendidikan, dan pengalaman kerja.

\section{Hubungan Insentif dengan Kinerja Perawat}

Hasil analisis hubungan insentif dengan kinerja, baik yang dipersepsikan perawat maupun berdasar observasi menunjukkan tidak ada hubungan antara insentif dengan kinerja perawat. Hal ini sesuai dengan penelitian Lusiani (2006); Muharyati (2006). Namun, hasil ini tidak berkesesuaian dengan penelitian yang berpendapat bahwa program insentif merupakan upaya untuk memperkuat hubungan kinerja-imbalan dan dengan demikian memotivasi kalangan karyawan yang terpengaruh (Simamora, 2004; Wibowo, 2007; Rivai \& Sagala, 2009 ).

Retnowati (2001); Siagian (2003), yang menjelaskan bahwa persepsi mengenai imbalan terjadi karena ada faktor yang mempengaruhi meliputi: 
sikap, motif, kepentingan, minat, pengalaman, dan harapan. Nawawi (2008) menjelaskan bahwa konsep kekuatan kebutuhan untuk memotivasi tidak lama, karena setelah terpenuhi akan melemah atau kehilangan kekuatannya dalam memotivasi.

Hal yang menyebabkan insentif tidak berhubungan dengan kinerja perawat di RSUD Kota $C$ terletak pada kekuatan insentif yang sudah tidak efektif sebagai salah satu motivator seseorang, karena kekuatan untuk memotivasi kebutuhan individu melalui pemberian insentif tidak lama. Kecenderungan kekuatan insentif akan melemah dalam memotivasi seiring dengan perjalanan seseorang dalam mengembangkan dirinya.

Penetapan besaran insentif yang bervariasi di setiap institusi dan dasar penghitungan pemberian insentif berdasar grading yang hanya memiliki kontribusi $25 \%$ dari total kriteria juga menyebabkan kurang terwakilinya kemampuan dan aspek profesionalisme perawat sehingga menyebabkan penilaian pemberian insentif menjadi subjektif dan tidak berhubungan dengan kinerja.

\section{Hubungan Pencapaian dengan Kinerja perawat}

Hasil analisis menunjukkan bahwa tidak ada hubungan antara pencapaian dengan kinerja perawat. Hasil ini sesuai dengan Lannasari (2005), namun tidak sejalan Wardoyo (1996) yang menyatakan bahwa keinginan berprestasi dihubungkan dengan motivasi.

Peneliti menganalisis tidak adanya hubungan antara pencapaian dengan kinerja perawat disebabkan oleh faktor motivasi berprestasi berbeda setiap individu. Untuk menciptakan motivasi pencapaian prestasi, maka organisasi perlu menata batasan desain kerja dan manajemen kinerja melalui pengaturan kompetensi dan mekanisme penghargaan yang menyentuh aspek profesionalisme.

\section{Hubungan Pengakuan dengan Kinerja perawat}

Hasil bivariat menunjukkan bahwa tidak ada hubungan antara pengakuan dengan kinerja perawat baik yang dipersepsikan oleh perawat maupun berdasarkan observasi. Hasil ini tidak sejalan dengan penelitian yang menyatakan bahwa motivasi bekerja pada perawat dihubungkan dengan pengakuan berupa promosi jabatan (Lusiani, 2006; Lannasari, 2005). Hasil penelitian juga tidak sesuai dengan konsep teori penguatan (reinforcement) yang mempergunakan prinsip "hukum ganjaran (law of effect)" yang menyatakan bahwa suatu tingkah laku yang mendapat ganjaran menyenangkan akan mengalami penguatan dan cenderung untuk diulangi (Armstrong \& Murlis, 2003).

Peneliti menyimpulkan bahwa hal ini terjadi disebabkan oleh karena batasan dan bentuk pengakuan terhadap pencapaian prestasi kerja perawat yang belum terstruktur, sehingga berdasarkan data hasil penelitian menunjukkan bahwa sebagian besar perawat merasa promosi dilakukan hanya untuk kemajuan rumah sakit dan bukan atas prestasi personal. Oleh karena itu, desain sistem reward menyeluruh, terstruktur serta adil sangat dibutuhkan untuk mendukung efektifitas sistem penghargaan.

\section{Hubungan Tanggung Jawab dengan Kinerja Perawat}

Hasil analisis menunjukkan tidak ada hubungan antara tanggung jawab dengan kinerja perawat. Hasil ini tidak sejalan dengan Amstrong dan Murlis (2003); Lannasari (2005); yang mengatakan bahwa seseorang bisa termotivasi dengan memberinya tanggung jawab besar atas pekerjaannya, individu pada umumnya belajar dibawah kondisi tertentu, bukan hanya menerima tetapi juga mencari tanggung jawab.

Peneliti menyimpulkan bahwa ketidaksesuaian hasil penelitian disebabkan oleh pemberian tanggung jawab yang dirasakan belum optimal, yang didukung dengan data adanya perawat lebih banyak merasa terpaksa melakukan hal-hal baru berhubungan dengan pekerjaan. Tanggung jawab yang belum terstruktur secara jelas dan bersinergi dengan pengakuan juga menyebabkan kurang maksimal peningkatan kinerja sesuai harapan. 
Tabel 3. Pemodelan Akhir Regresi Logistik Variabel Sistem Penghargaan, Karakteristik Individu dengan Persepsi Kinerja Perawat dalam Memberikan Asuhan Keperawatan

\begin{tabular}{cccccc}
\hline Variabel & B & SE & p & OR & 95\% CI \\
\hline Pengaruh & 1,618 & 0,601 & 0,007 & 5,042 & $1,553-16,367$ \\
\hline
\end{tabular}

* bermakna pada $\alpha=0,05$

\section{Hubungan Pengaruh dengan Kinerja Perawat}

Hasil bivariat menunjukkan ada hubungan yang bermakna antara pengaruh dengan kinerja perawat yang dipersepsikan perawat. Hasil ini sesuai dengan Armstrong dan Murlis (2003); Setiasih (2006), mengemukakan salah satu faktor yang bisa membuat kinerja seorang individu menjadi meningkat adalah dengan membuatnya termotivasi untuk mempengaruhi dan berkuasa.

Studi penelitian lain dikemukakan Dewettinck, Singh, dan Buyens (2003); Chen (2008); yang menyatakan bahwa faktor yang berhubungan dengan persepsi puas terhadap kinerja perawat, diantaranya yaitu persepsi terhadap kemampuan mempengaruhi organisasi seperti kontrol dan pengambilan keputusan. Peneliti menganalisis bahwa pengaruh sebagai salah satu kebutuhan manusia dapat menjadi alternatif metode pemberian penghargaan kepada individu karyawan, karena sub variabel pengaruh termasuk dalam dimensi kepuasan kerja perawat.

\section{Hubungan Pertumbuhan Diri dengan Kinerja Perawat}

Hasil bivariat hanya ditemukan ada hubungan yang bermakna antara pertumbuhan diri dengan kinerja yang dipersepsikan oleh perawat. Hasil penelitian ini sesuai dengan hasil penelitian yang dilakukan oleh Chanafie (2005); Lannasari (2005); yang menjelaskan bahwa persepsi jenjang karir menjadi salah satu faktor yang berhubungan dengan persepsi puas terhadap kinerja perawat.

Hal ini didukung oleh pendapat Robbins (2001) yang menyatakan karir adalah suatu deretan posisi yang diduduki oleh seseorang selama perjalanan usianya. Marquis dan Huston (2006); Sitinjak
(2008) mengemukakan perawat perlu memiliki tanggung jawab utama terhadap karirnya sendiri.

Perawat harus mengenali karir sebagai jenjang yang dipilih atau dikontrak yang dibuat seseorang untuk berkontribusi dalam suatu profesi dengan memuaskan, sehingga untuk mendapatkan karir yang berhasil harus dibangun oleh diri perawat sendiri dan penilaian dari lingkungan terhadap analisa pekerjaannya, maka perawat harus terus memelihara dan menjaga pengetahuan dan keterampilannya untuk tetap mutakhir dengan cara melaksanakan kinerja dengan baik (Robbins, 2001; Chanafie, 2005).

\section{Hubungan skala grading dengan kinerja perawat}

Hasil analisis bivariat didapatkan tidak ada hubungan antara skala grading dengan kinerja perawat baik berdasarkan observasi maupun yang dipersepsikan oleh perawat. Hasil ini tidak sesuai dengan Chanafie (2005); Lannasari (2005); Lusiani (2006); Sitinjak (2008) yang mendapatkan data bahwa ada hubungan yang bermakna antara jenjang karir dengan kinerja.

Depkes RI dan PPNI (2006) menjelaskan bahwa sistem jenjang karir sebagai salah satu komponen sistem penghargaan non finansial kepada perawat merupakan aspek pengakuan pencapaian kinerja dan disusun dengan berbagai tujuan, diantaranya untuk meningkatkan kinerja dan profesionalisme serta akuntabilitas perawat sesuai dengan bidang pekerjaan melalui peningkatan kompetensi. Marquis dan Huston (2006) menjelaskan bahwa manajemen karir berfokus pada tanggung jawab organisasi untuk pengembangan karir dan jenjang karir tidak hanya perlu dikembangkan, tetapi juga perlu dikomunikasikan kepada staf dan diimplementasikan secara konsisten. 
Tabel 4. Hasil Analisis Pemodelan Akhir Regresi Logistik Variabel Sistem Penghargaan, Karakteristik Individu dengan Kinerja Perawat Berdasarkan Observasi dalam Memberikan Asuhan Keperawatan

\begin{tabular}{cccccc}
\hline Variabel & B & SE & p & OR & $\mathbf{9 5 \%}$ CI \\
\hline Pertumbuhan diri & 1,029 & 0,587 & 0,080 & 2,798 & $0,885-8,844$ \\
\hline
\end{tabular}

* bermakna pada $\alpha=0,05$

Terkait dengan hasil penelitian yang tidak bermakna ini, maka peneliti menganalisis penyebabnya adalah karena sistem grading (PK I - PK IV) belum menjadi jenjang karir perawat yang efektif di RSUD Kota C. Mengingat ada beberapa aspek yang dirasakan kurang menyentuh unsur profesionalisme dan kompetensi karyawan secara akurat, yang masuk ke dalam kriteria penjenjangan seperti status kepegawaian, pelatihan, penilaian hasil kerja. Hal ini perlu dilakukan penataan ulang terhadap sistem penjenjangan yang diberlakukan di RSUD Kota C karena bila melihat teori dan konsep jenjang karir keperawatan, jenjang karir seharusnya dibuat berdasarkan 3 hal utama yaitu pendidikan, masa kerja dan uji kompetensi. Selain itu, jenjang karir hendaknya menjadi penentu utama sistem insentif yang ada.

\section{Variabel yang Paling Berhubungan dengan Kinerja Perawat dalam Melaksanakan Asuhan Keperawatan}

Pengaruh menjadi faktor dominan hubungan sistem penghargaan dengan kinerja yang dipersepsikan oleh perawat. Organisasi melalui kebijakan partisipasi bisa memotivasi karyawan dengan cara memberi kesempatan untuk mengungkapkan gagasannya, kesempatan agar pandangannya didengar dan bertindak sesuai pandangannya tersebut.

Pertumbuhan diri menjadi faktor dominan hubungan sistem penghargaan dengan kinerja perawat observasi. Maslow dalam Armstrong dan Murlis (2003) mendefenisikan bahwa pemenuhan diri sebagai "kebutuhan untuk mengembangkan potensi dan keterampilan untuk menjadi". Adanya kesempatan belajar, mengikuti kursus atau program yang bergengsi serta peluang untuk mendapatkan keterampilan baru, bisa menjadi motivator yang ampuh guna meningkatkan kinerja.

\section{Kesimpulan}

Hasil penelitian menunjukkan bahwa sistem penghargaan pengaruh dan pertumbuhan diri mempengaruhi kinerja yang dipersepsikan oleh perawat. Sedangkan, sistem penghargaan insentif, pencapaian, pengakuan, dan tanggung jawab tidak mempengaruhi kinerja, baik yang dipersepsikan oleh perawat maupun berdasarkan observasi. Sebagian perawat mempersepsikan tinggi tentang sistem penghargaan yang diterima meliputi pencapaian, pengakuan, pengaruh, pertumbuhan diri. Sebagian perawat juga memiliki kinerja baik dalam melaksanakan asuhan keperawatan (menurut persepsi perawat maupun observasi).

Motivasi pencapaian prestasi perlu dilakukan oleh organisasi melalui penataan batasan desain kerja dan manajemen kinerja melalui pengaturan kompetensi dan mekanisme penghargaan, strukturisasi mekanisme pengakuan, promosi yang adil serta tanggung jawab yang terstruktur jelas akan meningkatkan kinerja sesuai harapan. Upaya melibatkan karyawan dalam kegiatan rumah sakit, dengan mengggunakan umpan balik yang diberikan oleh karyawan sebagai dasar dalam pengambilan keputusan, menjadi upaya penting untuk meningkatkan kinerja. Bidang keperawatan hendaknya membuat perencanaan pengembangan pendidikan, pelatihan, sebagai bentuk penghargaan terhadap staf yang telah bekerja dengan baik dan berprestasi, selain itu sistem grading hendaknya disusun dengan kriteria hanya pada aspek kompetensi, pendidikan, dan masa kerja sesuai ketentuan Depkes RI (MS, YR, RR).

\section{Referensi}

Adji, I. (2002). Faktor-faktor yang berhubungan dengan kinerja perawat di ruang rawat inap RSU Raden Mattaher Jambi tahun 2002 
(Tesis master, tidak dipublikasikan). FKM UI, Depok.

Al-Ahmadi, H. (2009). Factors affecting performance of hospital nurses in Riyadh Region, Saudi Arabia. International Journal of Health Care Quality Assurance, 22 (1), 40-54.

Armstrong, \& Murlis. (2003). Reward management (1st Ed.). Jakarta: Gramedia.

Chanafie, D. (2005). Hubungan persepsi perawat pelaksana tentang jenjang karir dengan kepuasan kerja di RSUD Budhi Asih Jakarta (Tesis master, tidak dipublikasikan). Program Pascasarjana FIK UI, Depok.

Chen, Y.M. (2008). Nurses' work environment and satisfaction (Dissertation, Nursing-University of Maryland). Nursing-University of Maryland, Baltimore. Diperoleh dari http://archive.hshsl.umaryland.edu/.

Dewettinck, K., Singh, J., \& Buyens, D. (2003). Psychology empowerment in the workplace. Reviewing the empowerment effect on critical work outcomes. Diperoleh dari http://www. vlerick.com/en/2702VLK/version/default/part/ AttachmentData/data/vlgms-wp-2003-29.pdf.

Depkes RI, \& PPNI. (2006). Rancangan pedoman pengembangan sistem jenjang karir profesional perawat. Jakarta: PPNI.

Gillies, D. A. (1996). Manajemen keperawatan: Suatu pendekatan sistem (Alih bahasa D. Sukmana, dkk.) (Edisi Ke-2). Philadelphia: WB Saunders Company.

Ilyas, Y. (2002). Kinerja: Teori, penilaian, dan penelitian. Depok: Pusat Kajian Ekonomi Kesehatan FKM UI.

Lannasari. (2005). Hubungan karakteristik demografi dan persepsi terhadap reward system dengan motivasi kerja perawat pelaksana di RS Islam Jakarta (Tesis master, tidak dipublikasikan). Program Pascasarjana FIK UI, Depok.

Lusiani. (2006). Hubungan karakteristik individu dan sistem penghargaan dengan kinerja perawat menurut persepsi perawat pelaksana di RS Sumber Waras Jakarta (Tesis master, tidak dipublikasikan). FIK UI, Depok.

Marquis, B.L., \& Huston, C.J. (2006). Leadership roles and management functions in nursing theory and application (5th Ed.). Philadelphia: Lippincott Williams and Wilkins.
Muharyati, W. (2006) Faktor-faktor yang berhubungan dengan kinerja perawat dalam pendokumentasian asuhan keperawatan di ruang rawat inap RS Jiwa Prof. HB. Sa'anin Padang Tahun 2006 (Tesis master, tidak dipublikasikan). FKM UI, Depok.

Nawawi. (2008). Manajemen sumber daya manusia untuk bisnis yang kompetitif. Yogyakarta: Gadjah Mada University Press.

Notoatmodjo, S. (2009). Pengembangan sumber daya manusia. Jakarta: Rineka Cipta.

Retnowati. (2001). Persepsi terhadap sistem reward, kepuasan kerja dan motivasi kerja dosen menurut gender di Universitas Negeri Jakarta tahun 2001 (Tesis master, tidak dipublikasikan). FISIP UI, Depok.

Rivai, V. \& Sagala, E.J. (2009). Manajemen sumber daya manusia untuk perusahaan: Dari teori ke praktik (Edisi ke-2). Jakarta: Rajawali press.

Robbins, S.P. (2001). Perilaku organisasi: Konsep, kontroversi, aplikasi (Edisi ke-8). Jakarta: PT Prenhallindo.

Sastradijaya, H.J. (2004). Faktor-faktor yang berhubungan dengan kinerja perawat di ruang rawat inap RSUD Cilegon tahun 2004 (Tesis master, tidak dipublikasikan). FKM UI, Depok.

Setiasih, W. (2006). Hubungan antara kepuasan kerja perawat dengan kepuasan klien di RS Husada Jakarta (Tesis master tidak dipublikasikan). FIK UI, Depok.

Siagian, D. S. (2003). Manajemen sumber daya manusia. Jakarta: Buni Aksara.

Simamora, H. (2004). Manajemen sumber daya manusia (Edisi Ke-2). Yogyakarta: STIE YKPN.

Sitinjak, L. (2008) Pengaruh penerapan sistem jenjang karir terhadap kepuasan kerja perawat di RS PGI Tjikini Jakarta (Tesis master, tidak dipublikasikan). FIK UI, Depok.

Wardoyo, S. (1996). Faktor-faktor yang mempengaruhi motivasi berprestasi dalam menjalankan tugas bagi paramedis di puskesmas Kabupaten Magetan tahun 1995 (Tesis master, tidak dipublikasikan). FKM UI, Depok.

Wibowo. (2007). Manajemen Kinerja. Jakarta: PT Rajagrafindo Persada. 